\title{
PRODUCTION AND CHARACTERIZATION OF MONOCLONAL ANTIBODIES TO THE EDTA EXTRACT OF LEPTOSPIRA INTERROGANS, SEROVAR ICTEROHAEMORRHAGIAE
}

\author{
Lilian Terezinha de Queiroz Leite, Mauricio Resende, Wanderley de Souza, \\ Elizabeth R.S. Camargos and Matilde Cota Koury
}

\begin{abstract}
Monoclonal antibodies (MABs) were produced against an ethylenediaminetetraacetate (EDTA) extract of Leptospira interrogans serotar icterohaemorrhagiae being characterized by gel precipitation as IgM and IgG (IgG1 and IgG2b). The EDTA extract was detected as seteral bands by silver staining in SDS-PAGE. In the Western blot the bands around $20 \mathrm{KDa}$ reacted with a monoclonal antibody. 47B4D6, and was oxidized by periodate and uas not digested by pronase, suggesting that the determinant is of carbobydrate nature. Immunocytocbemistry, using colloidal gold labeling, sbowed that an EDTA extract determinant recognized by monoclonal antibody $47 B 4 D 6$, is localized under the onter entelope of serotar icterohaemorrhagiae. The $M A B$ raised against the EDTA extract was not able to protect bamsters from letbal challenge with limulent bomologous leptospires.
\end{abstract}

Key-words: Leptospira. Monoclonal antibodies. Passive protection.

Leptospirosis is a zoonosis of world-wide distribution, man being an accidental host.

Several attempts have been made to isolate leptospiral endotoxin. Lipopolysaccharides (LPS) extracted from leptospires showed endotoxic properties ${ }^{i 3}$. Some authors could not demonstrate any endotoxin activity in LPS extracted from leptospires $=28$. The EDTA extract from leptospires showed biological activities characteristic of endotoxin, although these effects were less intense than those of $E$. coli O111:B4 LPS ${ }^{-1}$

The development of hybridoma technology facilitated the production of monoclonal antibodies that could be used in identification, localization of antigenic determinants and studies of protective capacity.

\footnotetext{
Departamentos de Microbiologia e Morfologia do Instituto de Ciências Biológicas da Universidade Federal de Minas Gerais, Belo Horizonte, MG e Laboratório de Ultra-Estrutura Celular do Instituto de Biofísica Carlos Chagas Filho, Universidade Federal do Rio de Janeiro, Rio de Janeiro, RJ. This study was supported in part by Fundação de Amparo a Pesquisa do Estado de Minas Gerais (FAPEMIG).

Address to: Prof ${ }^{a}$. Matilde Cota Koury., Dept ${ }^{\circ}$ de Microbiologia/ICB/UFMG, Caixa Postal 486, 31270-901 Belo Horizonte, MG, Brasil.

Recebido para publicação em 23/11/95.
}

Leptospire genus specific determinant of the protein antigen (GP-Ag) of serovar kremastos recognized by monoclonal antibody was located on the sub-surface of the leptospiral envelope by immunoelectron microscopy and serovar specific TM antigen (LPS) was localized on the cell surface ${ }^{23}$. The same protein antigen was localized on the outer membrane of non pathogenic serovar andamana. The LPS of serovar bardjo was localized on the outer membrane by means of a monoclonal antibody revealed by immunogold staining in electron microscopy ${ }^{29}$. The determinant to which the MABs against the outer envelope $(\mathrm{OE})$ of serovar copenhageni were directed were localized in the leptospiral OE by the immunogold labeling technique ${ }^{16}$.

MABs against various antigenic substances of Leptospira were prepared and showed protective capacity. The MAB obtained against a glycolipid (OE) passively protected hamsters from leptospiral infection ${ }^{20}$. Hamsters immunized with the $M A B$ against serovar icterobaemorrhagiae were protected from challenge with the homologous serovar, but were not protected against the heterologous serovar ${ }^{31}$. The MAB against an OE fraction of serovar canicola protected hamsters ${ }^{30}$. Guinea pigs were protected from lethal infection with the daily administration of a MAB against 
Leite LTQ, Resende M, Souza W, Camargos ERS, Koury MC. Production and characterization of monoclonal antibodies to the EDTA extract of Leptospira interrogans, serovar icterohaemorrhagiae. Revista da Sociedade Brasileira de Medicina Tropical 29:483-489, set-out, 1996.

serovar copenhagen ${ }^{17}$. However, the MABs against the outer envelope of serovar copenbageni did not protect new-born guinea pigs from challenge with virulent leptospires ${ }^{16}$ and MAB LW4 against serovar lai Fraction 1 of $\mathrm{P}-\mathrm{Ag}$ also did not protect hamsters of lethal challenge ${ }^{20}$.

This paper reports the production of monoclonal antibodies against the EDTA extract of Leptospira interrogans, serovar icterobaemorrbagiae, their characterization, localization and passive protection test.

\section{MATERIALS AND METHODS}

Bacterial strain and growth conditions. Leptospira interrogans, serovar icterobaemorrbagiae, strain RGA, was grown in synthetic medium ${ }^{25}$ at $28^{\circ} \mathrm{C}$ for $7-10$ days and harvested by centrifugation at $6,800 \mathrm{~g}$ for 20 minutes at $4^{\circ} \mathrm{C}$ and kept at $-20^{\circ} \mathrm{C}$ until use. The virulent strain of leptospire was isolated from a patient with leptospirosis in Hospital Sarah Kubitschek (Belo Horizonte, MG, Brazil) and was grown in liquid medium $(\mathrm{EMJH})^{15}$. It was identified by the Polymerase Chain Reaction (PCR) as belonging to serovar icterohaemorrhagiae.

Preparation of the EDTA extract. Leptospira cells were extracted by the EDTA method of Leive and Shovlin ${ }^{19}$. The cells were washed three times with $0.12 \mathrm{M}$ Tris- $\mathrm{HCl}$, pH 8, ressuspended in the same buffer and brought to $37^{\circ} \mathrm{C}$. EDTA (in the same buffer) was added. The final volume contained $0.2 \mathrm{~g}$, wet weight, of cells per milliliter and 0.01M EDTA. After 4 minutes of gentle agitation at $37^{\circ} \mathrm{C}, \mathrm{MgCl}$ was added $(0.05 \mathrm{M}$ final concentration) and the cells were centrifuged at $6,800 \mathrm{~g}$ for 20 minutes. The supernatant was filtered through millipore filters $(0.45 \mathrm{~mm}$ pore size $)$, dialyzed at $4^{\circ} \mathrm{C}$, first against $0.1 \mathrm{M}$ sodium phosphate, $\mathrm{pH} 7.0$, for 16-24h and then against several changes of distilled water for 2-4 days. The non-dialyzable material was lyophilized. Hereafter, this material is termed the EDTA extract.

Partial chemical analyses. The LPS was measured by the method of Janda and Work ${ }^{14}$, using $E$. coli O111:B4 (Difco Labs.) as standard. Total carbohydrate content was measured by the phenol-sulfuric acid methods using glucose as standard. Protein was estimated according to the modified method of Lowry using bovine albumin as standard ${ }^{16}$.

Production and screening of monoclonal antibodies. Four weeks old female BALB/C mice were immunized intraperitoneally (i.p.)

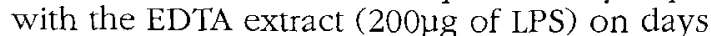
zero and 58. Spleen cells were harvested four days later and fusion was performed as described by Galfre and Milstein with P3X63/Ag 8653 myeloma cells. Hybridomas were grown in Dulbecco's minimal essential medium plus hypoxanthine, aminopterine and thymidine (HAT) supplemented with $20 \%$ fetal calf serum, $1.0 \mathrm{mM}$ pyruvate, $1.0 \mathrm{mM}$ oxaloacetic acid, $2.0 \mathrm{mM}$ L-glutamine, 0.1 each of a mixture of non-essential aminoacids, $15.0 \mathrm{mM}$ HEPES and 0.2 units of bovine insulin. Hybridomas were screened by enzyme-linked immunosorbent assay (ELISA) using the EDTA extract as antigen. They were cloned twice by limiting dilution. Three MABs with high reactivity in ELISA besicles good growth characteristics, were selected for further study.

Enzyme-linked immunosorbent assay. An indirect ELISA was carried out according to Adler et al ${ }^{1}$. Microtiter plates were coated either with the EDTA extract (200ng LPS/well) in a $0.06 \mathrm{M}$ carbonate-bicarbonate buffer, $\mathrm{pH}$ 9.6 , for $24 \mathrm{~h}$ at $4^{\circ} \mathrm{C}$. The wells were blocked with a $2 \%$ casein-phosphate buffer solution, $\mathrm{pH}$ 7.6. Between each stage, the plate was submitted to a series of washings with buffer solution-Tween 20 . The wells were probed with the supernatant for $1 \mathrm{~h}$ at room temperature. A goat anti-mouse horseradish peroxidase conjugate diluted at $1 / 800$ reacted with the antigen-antibody complex for 45 minutes at room temperature. The complex formed was revealed by $0.02 \mathrm{M}$ orto phenylen-diamine (Merck) diluted in a $0.01 \mathrm{M}$ citrate buffer and added of $0.03 \% \mathrm{HO}$ for 15 minutes in the dark. The reaction was stopped by $4 \mathrm{~N} \mathrm{H}_{2} . \mathrm{SO}_{4}$ and read in $492 \mu \mathrm{m}$ (Multiskan, Finlend). The cutoff considered was twice the average optical density (OD) of a leptospire-absorbed mouse serum plus one standard deviation.

Microscopic agglutination test (MAT). The MAT was performed according to the guidelines of the World Health Organization ${ }^{6}$.

Isotypes. The monoclonal antibodies were identified by the double immunodifusion method $^{22}$ using anti-mouse isotyping reagents (Sigma,USA).

Polyacrylamide gel electrophoresis and

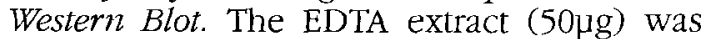
eletrophoresed on $12.5 \%$ polyacrylamide gel by the discontinuous method of Laemmli ${ }^{18}$ for 
Leite LTQ, Resende M, Souza W, Camargos ERS, Koury MC. Production and characterization of monoclonal antibodies to the EDTA extract of Leptospira interrogans, serovar icterohaemorrhagiae. Revista da Sociedade Brasileira de Medicina Tropical 29:483-489, set-out, 1996.

four hours at $150 \mathrm{~V}$ and either silver-stained ${ }^{12}$ or transblotted onto nitrocellulose membranes ${ }^{27}$. The membranes were sliced into strips, some of which were treated by periodate, pronase or were left untreated. One strip was then incubated for 1 hour with the anti-EDTA extract MAB. The other strips were incubated with anti-EDTA polyclonal antibody. The immunodetection was completed by incubating with a goat anti-mouse horseradish peroxidase conjugate. Diaminobenzidine and 4-chloronaphtol were used to reveal the bands $s^{11}$

EDTA extract treatment with pronase and periodate. Transblotted EDTA extract was treated with pronase $(100 \mu \mathrm{g} / \mathrm{ml}$-Promega) in PBS, pH 7.2 at $37^{\circ} \mathrm{C}$ for $24 \mathrm{~h}$. Periodate oxidation was performed as described by Omer et $\mathrm{al}^{21}$.

Electron microscopy. L. interrogans, serovar icterobaemorrbagiae was grown in liquid medium $^{15}$ for five days and harvested by centrifugation at $6.800 \mathrm{~g}$ for 15 minutes. The outer envelope was removed by three exposures to distilled water followed by centrifugation ${ }^{26}$. The pellet was fixed by $0.1 \%$ glutaraldehyde for 15 minutes at $4^{\circ} \mathrm{C}$ and washed three times with PBS $\mathrm{pH}$ 8. MAB 47B4D6 was bound to the leptospires after an incubation of one hour at $37^{\circ} \mathrm{C}$. Three more washing steps followed. A colloidal gold goat anti-mouse immunoglobulin (Auroprobe EM GAM 10, Ey Labs) was used as second label for one hour at $37^{\circ} \mathrm{C}$. After repeated washings, the pellet was deposited on a carbon-coated formvar copper grid. Excess liquid was removed with filter paper. The material was contrasted by $2 \%$ ammonium molybdate and observed, after drying, in a transmission electron microscope at $80 \mathrm{KV}$ (Zeiss)

Passive protection assay. Six groups of five golden hamsters (three weeks old, 30 grams average weight) were inoculated intraperitoneally with $1 \mathrm{ml}$ of culture supernatant and 24 hours later challenged by the same route with virulent L. interrogans, serovar icterobaemorrbagiae (107 cells $/ \mathrm{ml}$ ). Deaths were recorded and the animals showed symptoms typical of acute severe leptospirosis (arched back, icterus, hemorrhages).

\section{RESULTS}

Screening of monoclonal antibodies. The partial chemical analysis of the EDTA extract revealed the presence of LPS (37.8\%), protein (18.3\%) and polysaccharides (9.7\%)
Fourteen hybridoma cell lines were produced against the EDTA extract. The screening was made by ELISA. The culture supernatants, tested every 48 hours, reacted with the EDTA extract of serovar icterohaemorrbagiae and showed an OD of 0.419 to 0.969 . All of them were no agglutinating.

The MABs were of the following isotypes: 3 IgG1 (47B4D6, 47B4D11, 47B4F5), 7 IgG2b (47C1C4C8, 47C1C4D4, 47C1C5, 47C1C7, $47 \mathrm{~A} 5 \mathrm{G} 11 \mathrm{C} 9,47 \mathrm{~A} 5 \mathrm{G} 11 \mathrm{D} 2,47 \mathrm{~A} 5 \mathrm{~B} 4 \mathrm{~B} 11)$ and 1 IgM (47C1C11). Three could not be tested.

Three of them were chosen for the experiments, MABs 47B4D6, 47C1C4C8 and $47 \mathrm{C} 1 \mathrm{C} 11$. This selection was based on rapidity of growth, titers in ELISA and isotype.

Gel electrophoresis and immunoblotting antigens antigens. The SDS-PAGE of the EDTA extract demonstrated several bands. Some of them migrated to the same positions as those of $E$. coli O111:B4 LPS showing the same repetitive polysaccharide pattern (Figure 1).

The results of the determination of the chemical nature of the antigenic determinants of the EDTA extract by Western blot are shown in Figure 2. The polyclonal anti-EDTA extract antibody (Strip 1) revealed bands from 17 to 67 $\mathrm{kDa}$. When treated with periodate (Strip 2), the extract bands around $20 \mathrm{kDa}$ had their intensities diminished. Strip 3 shows the bands that were not affected by pronase treatment. Strip 4 shows the extract bands revealed by MAB 47B4D6. Also MABs 47C1C11 and $47 \mathrm{C} 1 \mathrm{C} 4 \mathrm{C} 8$ were tested and showed the same result. The bands were oxidized by periodate and not digested by pronase, suggesting that the determinant is a carbohydrate.

Electron microscopy. The localization of the EDTA extract determinant in leptospires of serovar icterobaemorrhagiae was done by MAB 47B4D6. Figure 3 shows an electronmicrograph of serovar icterobaemorrbagiae. Figure 3.1 shows a leptospire with its $\mathrm{OE}$ $(30,000 \mathrm{X})$ after reaction with $\mathrm{MAB} 47 \mathrm{~B} 4 \mathrm{D} 6$ and a colloidal gold goat anti-mouse conjugate. No binding of the gold particles is seen. Figure 3.2 shows a leptospire without the OE $(30,000 \mathrm{X})$ used as a control. Figure 3.3 shows a leptospire without the OE after reaction with MAB 47B4D6, with the goat antimouse colloidal gold particles of the conjugate bound to it. We observed that the MAB localized the EDTA extract determinant on the 
Leite LTQ, Resende M, Souza W. Camargos ERS, Koury MC. Production and characterization of monoclonal antibodies to the EDTA extract of Leptospira interrogans, serovar icterohaemorrhagiae. Revista da Sociedade Brasileira de Medicina Tropical 29:483-489, set-out, 1996.
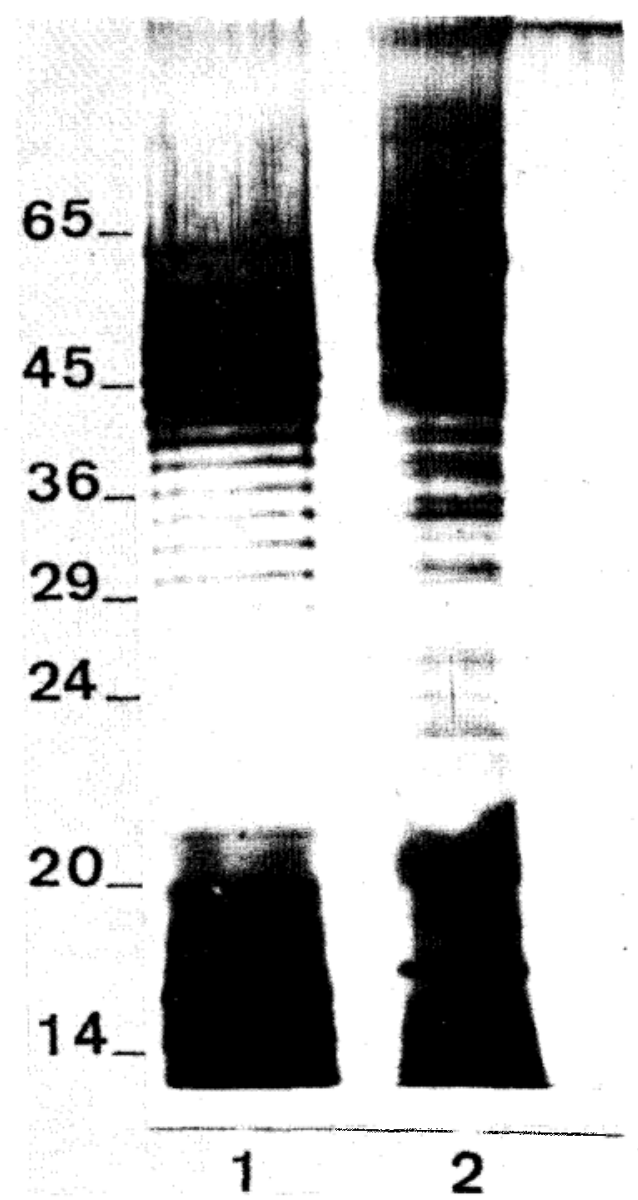

Figure 1 - Polyacrylamide gel electrophoresis of the EDTA extract of Leptospira interrogans, serolar icterohaemorrhagie silver stained. Lane 1 - E. coli 0111:B4 LPS (50ug). Lane 2 - EDTA extract of L. interrogans, serovar icterohaemorrhagiae $(50 \mu \mathrm{g})$. Apparent molecular mass markers are indicated on the left of the figure.
65

45

36

29.

24

20
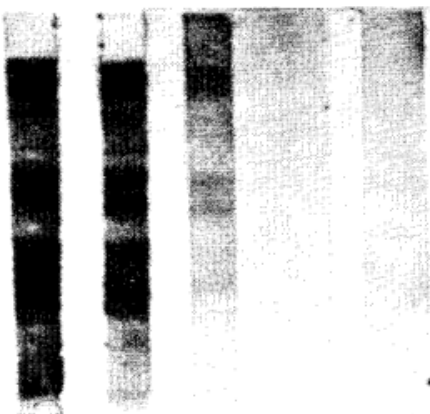

14.

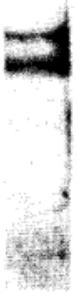

\section{3}

4

Figure 2 Determination of the chemical nature of the EDTA extract determinants by Western blot. Antigen:EDTA extract of Leptospira interrogans, serovar icterohaemomhagiae. Strip 1-EDTA extract revealed by polyclonal antibodies. Strip 2-EDTA extract revealed after treatment with periodate. Strip 3-EDTA extract revealed after treatment with pronase. Strip 4-EDTA extract revealed by Monoclonal antibody $47 B 4 D 6$. Apparent molecular mass markens are indicated on the left of the figure.

surface layer of the leptospire, under the $\mathrm{OE}$ $(56,000 \mathrm{X})$

Passive protection assay. The results of the passive protection assay with MAB 47B4D6 is shown in Table 1. The control animals died after an average survival time of 3.3 days. Those groins that received the undiluted monoclonal antibody had an average survival of 5.2 days and those that received the $1 / 10$ dilutions of 4.0 days. The kidneys of the
Table 1 - Passive protection of bansters by monuclonal antibody $47 B 406$ against challenge tuith Leptospira interrogunis, serovar icterobaenorthagiae.

Monoclonal antibody Number of survivors/ Survival average

\begin{tabular}{lcc}
\multicolumn{1}{c}{$47 \mathrm{~B} 4 \mathrm{D} 6$} & animals tested & (days) \\
\hline $\begin{array}{l}\text { Undiluted culture } \\
\text { supernatant }\end{array}$ & $0 / 5$ & 5.2 \\
$\begin{array}{l}\text { Culture supernatant } \\
\text { (1/10 dilution) }\end{array}$ & $0 / 5$ & 4.0 \\
Control & $0 / 5$ & 3.3 \\
\hline
\end{tabular}

Monoclonal antibody 47 $\overline{\mathrm{B} 4 \mathrm{D} 6}$-intraperitoneal inoculation

Leptospires-1 $\times 10^{\prime}$ cells $/ \mathrm{ml}$. intraperitoneal inoculation 
Leite LTQ, Resende M, Souza W. Camargos ERS, Koury MC. Production and characterization of monoclonal antibodies to the EDTA extract of Leptospira interrogans, serovar icterohaemorrhagiae. Revista da Sociedade Brasileira de Medicina Tropical 29:483-489, set-out, 1996.

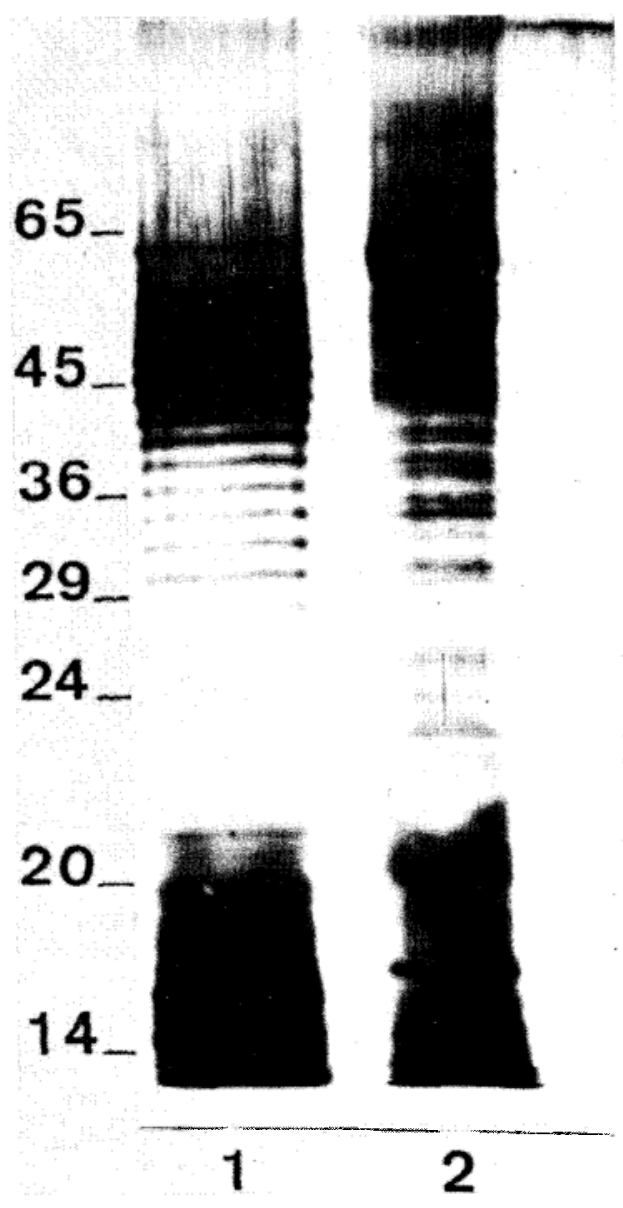

Figure 1 - Polyacrilamide gel electrophoresis of the EDTA extract of Leptospira interrogans, serotar icterohaemorrhaigie silver stained. Lane $1-\mathrm{E}$. coli O111:B4 LPS (50ug). Lane 2 - EDTA extract of L. interrogans, serotar icterohaemorrhagiae $(50 \mathrm{~kg})$ Apparent molecular mass markers are indicated on the left of the figure.

surface layer of the leptospire, under the $O E$ $(56,000 \mathrm{X})$.

Passive protection assay. The results of the passive protection assay with MAB 47B4D6 is shown in Table 1 . The control animals died after an average survival time of 3.3 days. Those grour's that received the undiluted monoclonal antibody had an average survival of 5.2 days and those that received the $1 / 10$ dilutions of 4.0 days. The kidneys of the

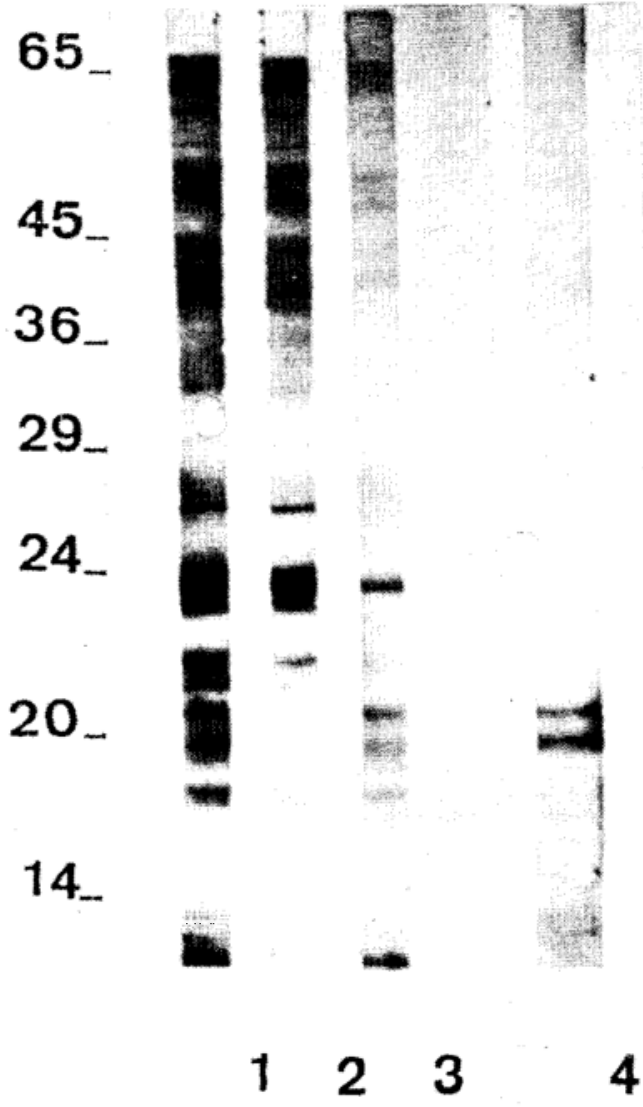

Figure 2 Determination of the chemical nature of the EDTA extract determinants by Western blot. Antigen:EDTA extract of Leptospira interrogans, serovar icterohaemorrhagiae. Strip 1-EDTA extract revealed by polyclonal antibodies. Strip 2-EDTA extract revealed after treatment uith periodate Strip 3-EDTA extract revealed after treatment uith pronase. Strip 4-EDTA extract revealed by Monoclonal antibody $47 B 4 D 6$. Apparent molecular mass markers are indicated on the left of the figure.

Table 1 - Passive protection of bamsters by moncclonal antibody $4754 D 6$ against challenge uith Leptospira interrogans. Serovar icterohaemotrhagiae.

\begin{tabular}{lcc}
$\begin{array}{c}\text { Monoclonal antibody } \\
47 \mathrm{~B} 4 \mathrm{D} 6\end{array}$ & $\begin{array}{c}\text { Number of survivors } \\
\text { animals tested }\end{array}$ & $\begin{array}{c}\text { Survival average } \\
\text { (days) }\end{array}$ \\
\hline $\begin{array}{l}\text { Undilured culture } \\
\text { supernatant }\end{array}$ & $0 / 5$ & 5.2 \\
$\begin{array}{l}\text { Culture supernatant } \\
\text { (1/10 dilution) }\end{array}$ & $0 / 5$ & 4.0 \\
Control & $0 / 5$ & 3.3 \\
\hline
\end{tabular}

Monoclonal antibody $\overline{47 \mathrm{~B}} \dot{\mathrm{D}} \mathrm{D} 6$-intraperitoneal inoculation Leprospires- $1 \times 10^{7}$ cellsiml. intraperitoneal inoculation 
Leite LTQ, Resende M, Souza W, Camargos ERS, Koury MC. Production and characterization of monoclonal antibodies to the EDTA extract of Leptospira interrogans, serovar icterohaemorrhagiae. Revista da Sociedade Brasileira de Medicina Tropical 29:483-489, set-out, 1996.

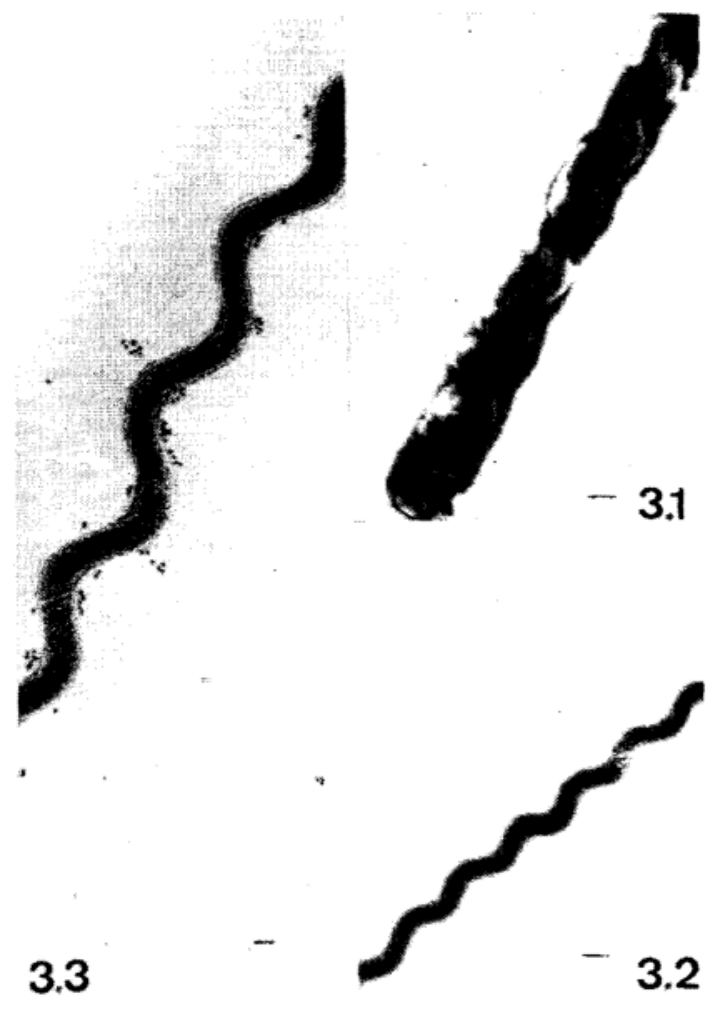

Figure 3 - Electronmicrograph of Leptospira interrogans, serovar icterohaemorrhagiae. 3.1 With the outer entelope after reaction with $M A B \quad 47 B 4 D 6$ and a colloidal gold goat anti-mouse conjugate. $30,000 x$ Bar $=0.14 m .3 .2$ Without the outer envelope, 30,000x. 3.3 Without the outer envelope bound to the monoclonal antibody $47 B 4 D 6$ and to a goat-anti-mouse colloidal gold conjugate, $56,000 x$, Bar $=0.2 \mu \mathrm{m}$.

animals were cultured for 30 days and no evidence of leptospira growth was observed.

\section{DISCUSSION}

Fourteen MABs against the EDTA extract were produced and characterized as IgG1 (3), $\operatorname{IgG} 2 \mathrm{~b}(7), \operatorname{IgM}(1)$ and three were not tested. All of them were non agglutinating. The MABs produced against the $O E$ of serovar copenhageni, were also non agglutinating ${ }^{16}$.

The study of the chemical nature of the antigenic determinant of the EDTA extract by PAGE and Western Blot (WB) techniques showed that this extract was not affected by pronase, but was oxidized by periodate, suggesting a carbohydrate nature.
Immunodiffusion and WB experiments showed that MAB MUM/F1-1 of serovar copenhageni reacted with a carbohydrate determinant in the leptospiral LPS $^{17}$. The MAB against serovar copenhageni also reacted with an epitope of carbohydrate nature when sonicated antigens were digested with pronase ${ }^{2 i}$. The MAB against the OE of serovar bardjo reacted with a protein determinant in WB experiments ${ }^{16}$.

When localizing the antigenic determinant, we observed that MAB 47B4D6 bound to the leptospira cell only after the removal of the OE, indicating that it is under this structure. The MAB against the genus specific protein antigen (GP-Ag) of serovar kremastos, labeled with peroxidase or iodinated, also bound to the sub-surface of the $\mathrm{OE}^{23}$. However, the $\mathrm{MAB}$ against GP-Ag of non-pathogenic serovar andamana bound to the $\mathrm{OE}^{2}$. The $\mathrm{MAB}$ against LPS of serovar bardjo or the OE of serovar copenhageni bound to the outer membrane of leptospire as evidenced by immunogold labeling techniques ${ }^{16} 29$.

The MAB against the EDTA extract of serovar icterobaemorrbagiae, when inoculated in hamsters could not protect them from lethal challenge with virulent leptospire. MAB against serovar copenbageni and MAB LW4 against serovar lai did not protect new-born guinea pigs $^{16}$ or hamsters ${ }^{20}$ against lethal infection. However, MAB against serovar copenhageni could passively protect guineapigs against lethal leptospirosis when daily administered in the dose of $175 \mathrm{mg}$ to ensure a protective titer $^{17}$. The MABs against serovar copenhageni also protected hamsters, dogs and monkeys ${ }^{24}$ and the MAB obtained against a glycolipid of the OE (PAg) from serovar lai protected hamsters from leptospiral infection ${ }^{20}$. Immunized hamsters with V1 MAB against serovar icterobaemorrbagiae were protected from lethal challenge with the homologous serovar $^{31}$.

In conclusion, we have a non agglutinating anti-EDTA extract MAB, that did not protect hamsters from challenge with virulent leptospires of the homologous serovar. The determinant is of carbohydrate nature and is located under the leptospiral OE.

\section{RESUMO}

Anticompos monoclonais (ACM) foram produzidos contra o extrato EDTA obtido de Leptospira interrogans, sorovar icterohaemorrhagiae. 
Leite LTQ, Resende M, Souza W, Camargos ERS, Koury MC. Production and characterization of monoclonal antibodies to the EDTA extract of Leptospira interrogans, serovar icterohaemorrhagiae. Revista da Sociedade Brasileira de Medicina Tropical 29:483-489, set-out, 1996.

Pelo teste de precipitação foram caracterizados como IgM e IgG (IgG1 e IgG2). A eletroforese en gel de poliacrilamida do extrato EDTA revelou diversas bandas quando corada pela prata. No "Western blot", as bandas em tomo de $20 \mathrm{kDa}$ reagiram com o AcM 47B4D6, foram oxidadas pelo periodato $e$ nâa digeridas pela pronase, sugerindo que o determinante é de natureza carboidrato. $O$ determinante reconbecido pelo AcM $47 B 4 D 6$ está localizado sob o envelope extemo como revelado pela imunocitoquimica usando marcação com ouro coloidal. O ACM contra extrato EDTA do sorovar icterohaemorrahagiae não protegeu bamsters quando inoculados com lepstopira bomóloga vimulenta.

Palauras-cbaves: Leptospira. Anticorpos monoclonais. Proteção passiva.

\section{REFERENCES}

1. Adler B, Murphy AM, Locarnini SA, Faine S. Detection of specific anti-leptospiral immunoglobulins $M$ and $G$ in human serum by solid-phase enzyme-linked immunosorbent assay. Journal of Clinical Microbiology 11:452-457, 1980.

2. Cacciapuoti B, Ciceroni L, Saito T, Ono E, Yanagava $\mathrm{R}$. Broad reacting surface antigens in Leptospira biflexa serovar andamana. Zentralbatt fur Bakteriologie Mikrobiologie und Hygiene Series A 269:86-99, 1988.

3. Caballero OLSD, Neto ED, Koury MC, Romanha AJ, Simpson AJG. Low-stringency PCR with diagnostically useful primers for identification of Leptospira serovars. Journal of Clinical Microbiology 32: 1369-1372, 1994.

4. De Souza L, Koury MC Isolation and biological activities of endotoxin from Leptospira interrogans. Canadian Journal of Microbiology 38:284-289, 1992.

5. Dubois M, Gilles KA, Hamilton JK, Rebers A, Smith F. Colorimetric method for determination of sugars and related substances. Analytical Chemistry 28:350-355, 1956.

6. Faine $S$ (Ed). Guidelines for the control of leptospirosis. WHO Offset Publication 37, Geneva, 1982.

7. Faine S,Adler B, Palit A. Chemical, serological and biological properties of a serotype-specific polysaccliaride antigen in Leptospira. Australian Journal of Experimental Biology and Medical Science 52: 311-319, 1974.
8. Finco DR, Low DG. Endotoxin properties of Leptospira canicola. American Journal of Veterinary Research 28:1863-1872, 1967.

9. Galfré G, Milstein C. Preparation of monoclonal antibodies; strategies and procedures. Methods in Enzymology 73:3-46, 1981.

10. Hartree EF Determination of protein: a modification of Lowry method that gives a linear photometric response. Analitical Biochemistry 48:422-427, 1972.

11. Hawkes R, Niday E, Gordon J. A dot immunobinding assay for monoclonal and other antibodies. Analitical Biochemistry 119:142-147, 1982.

12. Hitchcock P, B rown T. Morphological heterogeneity among Salmonella lipopolysaccharide chemotypes in silver-stained polyacrylamide gels. Journal of Bacteriology 154:269-277, 1983.

13. Isogai E, Isogai $H$, Kurebayashi $Y$, Y to N. Biological activities of leptospiral lipopolysaccharide Zentralbatt fuer Bakteriologie Mikrobiologie und Hygiene Series A 261:53-64, 1986.

14. Janda J. Work E. A colorimetric estimation of lipopolysaccharides. Febs Letters 16:343-345, 1971.

15. Johnson RC, Harris VJ. Differentiation of pathogenic and saprophytic leptospires. 1. Growth at low temperatures. Journal of Bacteriology 94:27-31, 1967.

16. Jost BH, Adler B, Vinh T, Faine, S. A monoclonal antibody reacting with a determinant on leptospiral lipopolysaccharide protects guinea pigs against leptospirosis. Journal of Medical Microbiology. 22:269-275, 1986.

17. Jost BH,Adler B, Faine S. Reaction of monoclonal antibodies with species-specific determinants in Leptospira inferrogans outer envelope. Journal of Medical Microbiology 27:51-57, 1986.

18. Laemmli UK. Cleavage of structural proteins during the assembly of the head of bacteriophage T4. Nature 227:680-685, 1970.

19. Leive L, Shovlin VK, Mergenhagen E. Physical, chemical, and immunological properties of lipopolysaccharide released from Escherichia coli by ethylenediamine tetraacetate. Journal of Biological Chemistry 243:6384-6391, 1968.

20. Masuzawa T, Nakamura R, Hashiguchi Y, Shimizu T, Iwamoto Y, Morita T, Yanagihara Y Immunological reactivity and passive protective activity of monoclonal antibodies against protective antigen (Pag) of Leptospira interrogans serovar lai. 
Leite LTQ, Resende M. Souza W, Camargos ERS, Koury MC. Production and characterization of monoclonal antibodies to the EDTA extract of Leptospira interrogans. serotar icterohaemorrhagiae. Revista da Sociedade Brasileira de Medicina Tropical 29:483-489, set-out, 1996.

Zentralbatt fuer Bakteriologie Mikrobiologie und Hygiene Series A 272: 328-336, 1990.

21. Omer PA, Manson M, Woody JN. Antibody to carbohydrate and polypeptide epitopes on the surface of schistosomula of $S$. mansoni in Egyptian patients with acute and chromic shistosomiasis. Parasitology 98:417-424, 1989.

22. Ouchterlony $O$. Diffusion in gel methods for immunological analysis. Progress inAllergy 5:178. 1968.

23. Sakamoto N, Ono E, Kida H. Production of monoclonal antibodies against leptospiral genusspecific protein antigen and localization of the antigen by immunoelectron microscopy. Zentralbatt fuer Bakteriologie Mikrobiologie und Hygiene Series A 259:557-563, 1985.

24. Schoone GJ, Everard COR, Korver H. An immunoprotective monoclonal antibody direct against Leptospira interrogans serovar copenhageni. Journal of General Microbiology 135:73-78, 1989.

25. Shenberg E. Growth of pathogenic Leptospira in chemically defined media.Journal of Bacteriology 93:1598-1606, 1967.

26. Takeya K, Mori R,Toda T. Studies on the structure of Leptospira as revealed by the electron microscope. Japanese Journal of Microbiology 1:99-101, 1957.
27. Towbin H, Staehelin T, Gordon J. Eletrophoretic transfer of protein from polyacrylamide gel to nitro cellulose sheets: procedure and some applications. Proceedings of the National Academy of Sciences of the United States of America 76:4350-4354, 1979.

28 . Vinh T, Adler B, Faine S. Glycolipoprotein cytotoxin from Leptospira interrogans serovar copenhageni. Journal of General Microbiology 132:111-123, 1986.

29. Vinh T, Shi M, Adler B, Faine S. Characterization and taxonomic significance of LPS of Leptospira interrogans, serovar hardjo. Journal of General Microbiology 135:2663-2673, 1989.

30. Yanagihara Y, Masuzawa T, Matsumoto T, ShimizuT, Takayanagi $\mathrm{K}$. Monoclonal antibody against surface antigen of Leptospira interrogans serovar canicola. Israel Journal of Veterinary Medicine 44:56-58, 1988.

31. Zhang WH, Xiu-Fen B, Qing-Dong D, Di-Kai N. Investigation on monoclonal antibodies against two serovars of the icterohaemorrhagiae serogroup of Leptospira. Zentralbatt fuer Bakteriologie Mikroskopie und Hygiene Series A 270:329-336, 1989. 